\title{
A Socio-Economic Proposed Theoretical Framework for Responding to The Covid-19 Outbreak
}

\author{
Astadi Pangarso ${ }^{1 *}$ \\ ${ }^{1}$ Telkom University, Business Administration Department, Jl. Telekomunikasi Terusan Buah Batu, \\ Bandung 40257, Indonesia
}

\begin{abstract}
One of the significant impacts of the Covid-19 outbreak was the need for physical distancing. Physical distancing causes changes in the order of human life within a relatively short amount of time. Physical distancing also directly causes various socio-economic problems, especially for small-medium enterprise (SME) businesses. The background of this research is the absence of a theoretical framework related to the socio-economic impacts of the Covid-19 outbreak based on previous quantitative research publications. This research aims to develop a theoretical framework on the socio-economic constructs for response to a Covid-19. This research uses the literature review method. The research publication data used for the literature review comes from the Scopus database until May 1, 2020, with restrictions to only quantitative research publication documents. The publication of quantitative research as research data is only derived from the business subject and uses quantitative data processing tools based on structural equation modelling (SEM) variance and covariance. From the research results, a theoretical framework was developed on the role of socio-economic moderation on the effect of internal resources on organizational performance and the role of socioeconomics as an antecedent of environmental behaviour. The proposed theoretical framework has the potential to be empirically tested in a futurerelated socio-economic response to a Covid-19 outbreak.
\end{abstract}

\section{Introduction}

The COVID-19 outbreak is a tragedy that has been quite shocking and has affected almost all essential aspects of human life on Earth [1]. The socio-economic aspect is one of the most human life and has been impacted by the Covid-19 outbreak [2 - 4]. Business and environmental aspects are part of socio-economics [5 - 10]. The real impact of the Covid19 outbreak from the business aspect is the phenomenon of declining financial income, mainly from small-medium enterprises (SME) [11 - 14] and potential changes in consumer environmental behaviour [15].

Based on research by [16 - 19], a research gap was identified from the database Scopus until May 1, 2020. There has been no theoretical or empirical research on Covid-19,

* Corresponding author: astadipangarso@telkomuniversity.ac.id 
especially in conjunction with the socio-economic side of the SME business. A theoretical framework on socio-economic factors is essential because the basis of empirical testing is mainly quantitative. The theoretical framework developed from the test results could potentially portray the impact of the Covid-19 outbreak on the business aspect. These two phenomena and research gaps trigger the emergence of research questions: "Do socioeconomic effect SME organizational performance?" and "is there any effect of socioeconomic factors on environmental behaviour?"

\section{Literature review}

A literature review is a process of gathering documents of scientific articles relevant to the topic and purpose of research. Such scientific articles have been published internationally in reputable sources of literature (journals, proceedings, books) for a specified period (usually an average of at least the past five years). After the document collection process, each document is explicitly screened based on the topic and method according to the research objectives. If there are incomplete documents (not by the topics and methods intended in the research objectives), the documents are not included in the other process. After the initial screening process, international scientific research publication documents were collected in this study depending on the topic and method to be analyzed and criticized. The purpose of analysis and criticism was to identify a research gap. With the discovery of a specific research gap, the importance of theoretical research was identified. The literature review process in this study started from searching for international scientific publications documents from a database of reputable and quality scientific documents (Scopus).

A discussion of four previous research documents successfully discovered and downloaded related to the search for documents in the Scopus database until May 1, 2020 with keywords: "Socio-economic" AND "Covid-19" can be seen in the Table 1 below:

Table 1. Previous research publications from Scopus with keywords "socio-economic" AND "Covid-19."

\begin{tabular}{|c|c|l|}
\hline No & Article source & \multicolumn{1}{c|}{ Findings related to "socio-economic" } \\
\hline 1 & {$[16]$} & $\begin{array}{l}\text { The impact of social distancing in the Kingdom of Saudi Arabia also } \\
\text { affects socio-economic related to mass religious activities such as the } \\
\text { Umrah. }\end{array}$ \\
\hline 2 & {$[17]$} & $\begin{array}{l}\text { The narrative impacts of the socio-economic on Covid-19 sufferers in } \\
\text { France. }\end{array}$ \\
\hline 3 & {$[18]$} & $\begin{array}{l}\text { The socio-economic restriction is one of the mitigation measures globally } \\
\text { carried out by various countries to minimize risks due to the Covid-19 } \\
\text { pandemic. Forms of socio-economic restrictions include the closure of } \\
\text { places where there is the potential for the emergence of a mass crowd, } \\
\text { such as schools/campuses, recreational areas and sports.. }\end{array}$ \\
\hline 4 & {$[19]$} & $\begin{array}{l}\text { The Covid-19 outbreak is thought to have originated from a bat which } \\
\text { caused the initial spread from an animal to humans and the continuation } \\
\text { from humans to Humans. Prevention of the Covid-19 virus outbreak } \\
\text { spread in terms of wildlife conservations. }\end{array}$ \\
\hline
\end{tabular}

Source: obtained from Scopus database

However, there is still an absence of research that builds a theoretical framework related to the socio-economic impacts of the pandemic from the SME business perspective. A theoretical framework is essential because the theoretical framework shows the effect of socio-economic concepts (as antecedents, mediators, moderators or consequents). A theoretical framework is also crucial because it is a foundation for research to be tested 
empirically. The result of theoretical framework testing is an empirical result finding. The finding from the empirical result is important because it gives scientific proof for the theoretical and practical contribution of research. Developing a theoretical framework requires prior empirical research, which is usually obtained from quantitative research because it clearly shows cause and effect [20, 21]. From thirty-eight documents search results in the Scopus database with keywords: "socio-economic" AND "partial least square" OR "Structural equation modelling" OR "SEM" OR "PLS" and limited (limit) based on four criteria, namely: published documents on the Scopus database between 2016-2020; subject area of business; source documents from journals and English language, so there are only four documents left. These four documents make socio-economic a construct within a theoretical framework and are empirically tested quantitatively using SEM. A discussion of the four previous research documents can be seen in Table 2 below:

Table 2. Previous research publications from Scopus with keywords "socio-economic" AND "partial least square" OR "structural equation modeling" OR "SEM" OR "PLS."

\begin{tabular}{|c|c|l|}
\hline No & $\begin{array}{c}\text { Article } \\
\text { source }\end{array}$ & \multicolumn{1}{c|}{ Possible research gap } \\
\hline 1 & $\begin{array}{c}{[20],} \\
{[21]}\end{array}$ & $\begin{array}{l}\text { It is still possible to be re-tested for different contexts, countries and methodologies } \\
\text { for the role of socio-economic moderation on the influence of entrepreneurial } \\
\text { orientation on financial performance and social performance; business planning on } \\
\text { financial performance and social salience on financial performance }\end{array}$ \\
\hline 2 & {$[22]$} & $\begin{array}{l}\text { It is still possible to be re-tested for different contexts, countries and methodologies } \\
\text { about the direct influence of socio-economic on environmental behavior }\end{array}$ \\
\hline 3 & {$[23]$} & - \\
\hline 4 & {$[24]$} & - \\
\hline
\end{tabular}

Source: obtained from Scopus database

\section{Methods}

This research is a theoretical paper [25] or conceptual paper. The data collected in this study is from research articles published and shared via the Scopus database. The Scopus database is one of the reputable publication indexes for scientific research publications [26]. A literature review methodology is used in the study. Documents were searched from the Scopus database on May 1, 2020; the database was accessed through a campus account. The keywords: "socio-economic" AND "Covid-19" were used to search for documents, and only five were found.

Four documents could be downloaded from the five documents obtained using the keyword "socio-economic" AND "Covid-19". These four documents are research journal articles from [16 - 19]. Furthermore, to be more specific searched keywords: "socioeconomic" AND "partial least square" OR "Structural equation modelling" OR "SEM" OR "PLS" and limited (limit) based on four criteria, namely: documents published in the Scopus database year between 2016 and 2020; subject area of business; source documents from journals and English language and founded 38 documents.

A basic search with the second group of keywords was conducted for various reasons: (1) there is no theoretical research that uses a quantitative research approach to examine socio-economic constructs following the occurrence of the Covid-19 pandemic. Theoretical research becomes the basis of empirical research on the socio-economic construct, especially in the business field. (2) To realize empirical research, especially quantitative research related to the socio-economic construct in the business field, the data obtained after the pandemic COVID-19 first needed to be developed into a theoretical framework. (3) Quantitative research tends to be more comfortable, cheaper and faster to do concerning data collection than quantitative research, especially in the post-pandemic COVID-19 
period using various online survey media. (4) The limitation of using the SEM method and PLS was that research publications that use SEM or PLS have a clear theoretical framework that simplifies and accelerates the process of preparing a new proposed theoretical framework. Also, PLS is SEM variance that has been used in many international and reputable research publications as a quantitative research tool to process data [27 - 31].

\section{Results}

This research produced the following theoretical framework proposal based on the observed research gap (Fig. 1):

This theoretical framework proposal contains several propositions, six of which include:

- Proposition 1: The role of socio-economic moderation on the influence of entrepreneurial orientation on financial performance.

- Proposition 2: The role of socio-economic moderation on the influence of entrepreneurial orientation on social performance.

- Proposition 3: The role of socio-economic moderation on the effect of a business plan on financial performance.

- $\quad$ Proposition 4: The role of socio-economic moderation on the effect of a business plan on social performance.

- $\quad$ Proposition 5: The role of socio-economic moderation on the effect of social salience on social performance.

- $\quad$ Proposition 6: The direct effect of socio-economic on environmental behavior.

- Proposition 7: The direct effect of socio-economic on financial performance.

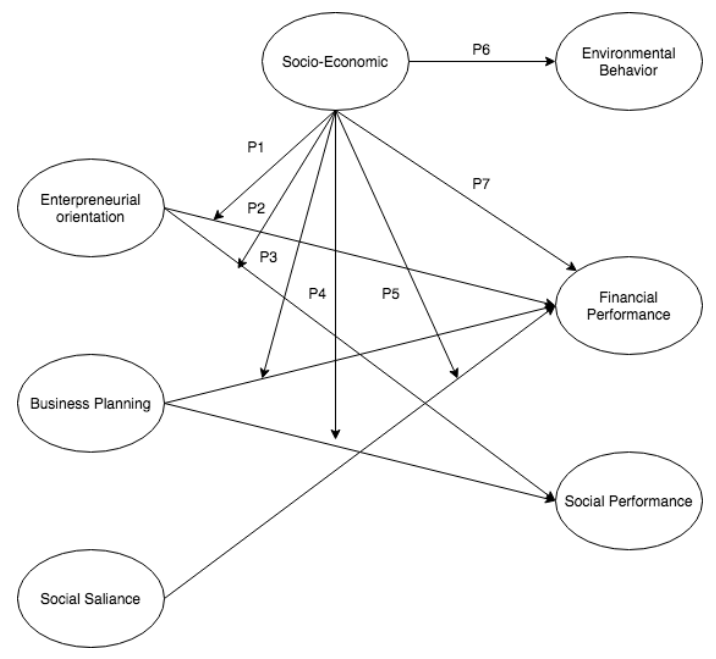

Fig. 1. Proposed theoretical framework.

Proposition 1-5 is based on RBV theory and supported by prior research publication conducted by [20,21]. Proposition 6 is based on planned behaviour theory and supported by prior research publication [22]. Proposition 7 is based on the RBV theory and supported by prior research publication conducted by [32].

The COVID-19 outbreak can cause a decrease in the financial and social performance of SMEs, and efforts should be made to improve it. The COVID-19 outbreak also causes human attention to shift to health and the environment, which opens up opportunities for improving environmental behaviour [4]. The role of socio-economic 
constructs in the proposed theoretical framework is as a moderator and an antecedent. This proposed theoretical model originality combines two theories, namely, RBV and planned behaviour theories. The proposed theoretical model also includes the direct effect of socioeconomic factors on financial performance. Karadag [32] states that (1) there is a direct relationship between some socio-economic indicators and financial performance. (2) There is a significant effect of SME owners' level of education and the SME's size on financial performance. (3) There is no significant effect of differences in the types of SME industries on financial performance. So, the direct socio-economic effect could be added as a proposition in the proposed theoretical framework. The socio-economic construct modifies the relationship between resources and performance and as an antecedent for environmental behaviour.

\section{Discussion}

A theoretical framework is helpful for the hypothesis testing process in future empirical research. In the proposed theoretical framework, two constructs exhibit differences in methodology based on prior research publications, namely the unit of analysis. Propositions 1-5 based on research Cheah et al. [20, 21] and proposition seven based on Karadag [32] use organizational analysis units. In the unit analysis of the organization, the object of research is the organization. Usually, the respondents representing the organization are leaders or members of the organization. They are deemed worthy of representing the organization and understanding the constructs in the proposed theoretical framework or using multiple respondents [33,34]. While Proposition 6 is based on Widhiastuti et al. [22] research, it uses individual unit analysis (consumers) because it examines behaviour in the context of awareness of the concept of environmental friendliness. Proposition 6 later, if tested empirically in future studies, the unit of analysis may turn into an organization. So, proposition 6 examines the direct effect of socioeconomic constructs on organizational environmental behaviour. Organizational environmental behaviour can be measured based on the use of natural energy, waste management (solid and liquid); air pollution management; aesthetic impact; the impact of contamination on the ground; and other environmental risks [35]. So, the proposed theoretical framework ontology explains the role of socio-economic constructs in business organisations' performance and environmental behaviour, especially SMEs.

About the Covid-19 outbreak, it is suggested that SMEs can improve organizational performance and environmental behaviour. Some positive impacts of the Covid-19 outbreak on the environment include increasing air quality due to massive lockdowns at almost the same time in various places globally. One of them reduces carbon emission levels [36 - 44]. This positive impact can be helpful to provide more concrete evidence that it turns out if, under forced conditions, improvement of environmental quality is possible. The covid-19 outbreak resulted in developing a new habit referred to as the "new normal" [45]. With this new normal, the potential for encouragement to pay more attention to organizational environmental behaviour for the business sector has been increased, especially for SMEs. This can happen by utilizing the momentum of objective evidence of the positive impact of Covid-19 on the environment, one of which is in terms of improved air quality. Quantitative research based on theoretical frameworks on socio-economic impacts on environmental behaviour in SMEs is still very interesting researched and is expected to contribute both theoretically and practically, primarily about the Covid-19 outbreak. 


\section{Conclusion}

This research theoretically discovers a proposed theoretical framework related to the socio-economic construct from a business perspective. The proposed theoretical framework consists of several constructs: entrepreneurial orientation, business planning, social salience, socio-economic, environmental behaviour, financial performance, and social performance. The socio-economic construct plays two roles as a moderator in the effect of internal resources on organizational performance and as an antecedent to environmental behaviour and financial performance. This research is a theoretical paper that generates a proposed theoretical framework. Theoretically, this research contributes to (1) RBV theory $[46,47]$; the socio-economic concept contributes theoretically as a moderator in RBV theory. (2) The socio-economic concept becomes an antecedent of environmental behaviour that contributes to the theory of planned behaviour [48].

This study has a limitation in that only the Scopus database was considered the basis for the literature review. This opens up the opportunity for future research agendas to carry out similar studies using other databases such as the Web of Science. This research takes the form of a theoretical paper to open up opportunities for empirical testing in the future related to increased organizational performance and environmental behaviour for SMEs.

Acknowledgement: LPPM Telkom University.

\section{References}

1. D. E. Irawan., A. Pangarso., I. A. Ridlo, and A. Fuad. Telaah bibliometrik pola penyebaran pengetahuan tentang COVID-19 di dunia, 1-15 (2020) doi: https://doi.org/10.6084/m9.figshare.12084339.v3

2. UNDP. Socio-economic impact of COVID-19. (2020) Retrivied from https://www.undp.org/content/undp/en/home/coronavirus/socio-economic-impact-ofcovid-19.html

3. UNICEF. Rapid situation tracking for COVID-19 socioeconomic impacts. (2020) Retrivied from https://data.unicef.org/resources/rapid-situation-tracking-covid-19socioeconomic-impacts-data-viz/

4. M. A. Zambrano-Monserrate., M. A. Ruano., L. Sanchez-Alcalde. Indirect effects of COVID-19 on the environment, Sci. Total Environ. 728, 138813 (2020) doi: 10.1016/j.scitotenv.2020.138813

5. P. K. Ozili. COVID-19 in Africa: Socioeconomic Impact, Policy Response and Opportunities, SSRN Electron. J. (2020) doi: 10.2139/ssrn.3574767

6. M. Nicola et al. The Socio-Economic Implications of the Coronavirus and COVID-19 Pandemic: A Review, Int. J. Surg. 78, 185-193 (2020) doi: 10.1016/j.ijsu.2020.04.018

7. V. Stojkoski, Z. Utkovski, P. Jolakoski, D. Tevdovski, and L. Kocarev. The SocioEconomic Determinants of the Coronavirus Disease (COVID-19) Pandemic, SSRN Electron. J. 1-30 (2020) doi: 10.2139/ssrn.3576037 
8. S. Saadat, D. Rawtani, and C. M. Hussain. Environmental perspective of COVID-19, Sci. Total Environ. 728, 138870 (2020) doi: 10.1016/j.scitotenv.2020.138870

9. A. H. Rahdari. Developing a fuzzy corporate performance rating system: A petrochemical industry case study, J. Clean. Prod. 131, 421-434 (2016) doi: 10.1016/j.jclepro.2016.05.007

10. M. Mitręga, V. Spáčil, and G. Pfajfar. Is partner knowledge equally important for businesses from post-communist countries? - comparative study of polish and Slovenian companies, J. East Eur. Manag. Stud. 24, 155-177 (2019) doi: 10.5771/0949-6181-2019-1-155

11. ILO. Supporting small and medium enterprises through the COVID-19 crisis (2020) Retrivied from https://www.ilo.org/jakarta/info/public/pr/WCMS_741502/lang-en/index.htm

12. S. Hadi, U. I. Indonesia, S. Supardi, and U. M. Kudus. Revitalization Strategy for Small and Medium Enterprises after Corona Virus Disease Pandemic (Covid-19) in Yogyakarta (2020) doi: 10.37896/JXAT12.04/1149

13. F. Fitriasari. How do Small and Medium-sized Enterprises (SME) survive the COVID19 outbreak? J. Inov. Ekon. 5 (2020) doi: 10.22219/JIKO.V5I3.11838.

14. M. A. Ganaie, M. Enterprises, D. Authority, and F. Zafar. Survey Report : Impact of COVID-19 on SMEs Policy \& Planning Division (2020) doi: 10.13140/RG.2.2.21236.09607

15. S. Jribi, H. Ben Ismail, D. Doggui, and H. Debbabi. COVID-19 virus outbreak lockdown: What impacts on household food wastage? Environ. Dev. Sustain. 22, 3939-3955 (2020) doi: 10.1007/s10668-020-00740-y

16. S. Yezli and A. Khan. COVID-19 social distancing in the Kingdom of Saudi Arabia: Bold measures in the face of political, economic, social and religious challenges, Travel Med. Infect. Dis. $101692 \quad$ (2020) doi: https://doi.org/10.1016/j.tmaid.2020.101692

17. A. Chevance et al. Ensuring mental health care during the SARS-CoV-2 epidemic in France: A narrative review, Encephale, 1-11 (2020) doi: 10.1016/j.encep.2020.03.001

18. Y. Bruinen de Bruin et al. Initial impacts of global risk mitigation measures taken during the combatting of the COVID-19 pandemic, Saf. Sci. 128, 104773 (2020) doi: 10.1016/j.ssci.2020.104773

19. J. Yuan, Y. Lu, X. Cao, and H. Cui. Regulating wildlife conservation and food safety to prevent human exposure to novel virus, Ecosyst. Heal. Sustain. 6 (2020) doi: 
$10.1080 / 20964129.2020 .1741325$

20. J. Cheah, A. Amran, and S. Yahya. Internal oriented resources and social enterprises' performance: How can social enterprises help themselves before helping others? J. Clean. Prod. 211, 607-619 (2019) doi: 10.1016/j.jclepro.2018.11.203

21. J. Cheah, A. Amran, and S. Yahya. External oriented resources and social enterprises' performance: The dominant mediating role of formal business planning, J. Clean. Prod. 236, 117693 (2019) doi: 10.1016/j.jclepro.2019.117693.

22. R. Widhiastuti, R. Setiyani, Kardiyem, and W. Rahmaningtyas. The role of responsibility feeling in mediating the effects of the environmental education course, socio-economic conditions, and awareness as the caliph on environmental behavior, J. Environ. Manag. Tour. 10, 1, 53-62 (2019) doi: 10.14505/jemt.v10.1(33).06

23. R. Megasari, Y. Budiawati, and A. Mulyaningsih. Factors affecting participation of women farmers in supporting family food security: Case study in Pandeglang regency, Indonesia, in IOP Conference Series: Earth and Environmental Science, 383 (2019) doi: 10.1088/1755-1315/383/1/012038

24. M. B. Pietrzak, A. P. Balcerzak, A. Gajdos, and Ł. Arendt. Entrepreneurial environment at regional level: The case of polish path towards sustainable socioeconomic development, Entrep. Sustain. Issues. 5, 2, 190-203 (2017) doi: 10.9770/jesi.2017.5.2(2)

25. L. L. Gilson and C. B. Goldberg. Editors' Comment: So, What Is a Conceptual Paper?, Gr. Organ. Manag. 40, 127-130 (2015) doi: 10.1177/1059601115576425

26. F. Franceschini, D. Maisano, and L. Mastrogiacomo. Empirical analysis and classification of database errors in Scopus and Web of Science Empirical analysis and classification of database errors in Scopus and Web of Science, J. Informetr. 10, 933953 (2016) doi: 10.1016/j.joi.2016.07.003

27. J. Benitez, J. Henseler, A. Castillo, and F. Schuberth. How to perform and report an impactful analysis using partial least squares: Guidelines for confirmatory and explanatory IS research, Inf. Manag. 57, 103168 (2020) doi: 10.1016/j.im.2019.05.003

28. J. Henseler et al. Common Beliefs and Reality About PLS: Comments on Rönkkö and Evermann (2013), Organ. Res. Methods. 17, 182-209 (2014) doi: $10.1177 / 1094428114526928$

29. W. L. Shiau, M. Sarstedt, and J. F. Hair. Internet research using partial least squares structural equation modeling (PLS-SEM), Internet Res. 29, 398-406 (2019) doi: 
10.1108/IntR-10-2018-0447

30. F. Ali, S. M. Rasoolimanesh, M. Sarstedt, C. M. Ringle, and K. Ryu. An assessment of the use of partial least squares structural equation modeling (PLS-SEM) in hospitality research, Int. J. Contemp. Hosp. Manag. 30, 514-538 (2018) doi: 10.1108/IJCHM-102016-0568

31. C. M. Ringle, M. Sarstedt, R. Mitchell, and P. Siegfried, Partial least squares structural equation modeling in HRM research, Int. J. Hum. Resour. Manag. 5192, 127 (2018) doi: 10.1080/09585192.2017.1416655

32. H. Karadag. The impact of industry, firm age and education level on financial management performance in small and medium-sized enterprises (SMEs): Evidence from Turkey, J. Entrep. Emerg. Econ. 9, 300-314, (2017) doi: 10.1108/JEEE-09-20160037

33. A. Pangarso, E. S. Astuti, K. Raharjo, and T. W. Afrianty. The impact of absorptive capacity and innovation ambidexterity on sustainable competitive advantage: the case of Indonesian higher education, Entrep. Sustain. Issues. 7, 2436-2455 (2020) doi: 10.9770/jesi.2020.7.3(65)

34. A. Pangarso, E. S. Astuti, K. Raharjo, and T. W. Afrianty. Data of innovation ambidexterity as a mediator in the absorptive capacity effect on sustainable competitive advantage, Data Br. 29, 105200 (2020) doi: 10.1016/j.dib.2020.105200

35. J. González-Benito, G. Lannelongue, and D. Queiruga. Stakeholders and environmental management systems: A synergistic influence on environmental imbalance, J. Clean. Prod. 19, 1622-1630 (2011) doi: 10.1016/j.jclepro.2011.05.013

36. S. Gautam, The Influence of COVID-19 on Air Quality in India: A Boon or Inutile, Bull. Environ. Contam. Toxicol. 104, 724-726 (2020) doi: 10.1007/s00128-02002877-y

37. P. Lal et al., The dark cloud with a silver lining: Assessing the impact of the SARS COVID-19 pandemic on the global environment, Sci. Total Environ. 732, 139297 (2020) doi: 10.1016/j.scitotenv.2020.139297

38. S. Sharma, M. Zhang, Anshika, J. Gao, H. Zhang, and S. H. Kota. Effect of restricted emissions during COVID-19 on air quality in India, Sci. Total Environ. 728, 138878 (2020) doi: 10.1016/j.scitotenv.2020.138878

39. I. Chakraborty and P. Maity. COVID-19 outbreak: Migration, effects on society, global environment and prevention," Sci. Total Environ. 728, 138882 (2020) doi: 10.1016/j.scitotenv.2020.138882 
40. Q. Wang and M. Su. A preliminary assessment of the impact of COVID-19 on environment - A case study of China, Sci. Total Environ. 728, 138915 (2020) doi: 10.1016/j.scitotenv.2020.138915

41. A. P. Yunus, Y. Masago, and Y. Hijioka. COVID-19 and surface water quality: Improved lake water quality during the lockdown, Sci. Total Environ. 731, 139012 (2020) doi: 10.1016/j.scitotenv.2020.139012

42. S. Mahato, S. Pal, and K. G. Ghosh. Effect of lockdown amid COVID-19 pandemic on air quality of the megacity Delhi, India, Sci. Total Environ. 730, 139086 (2020) doi: 10.1016/j.scitotenv.2020.139086

43. L. Li et al. Air quality changes during the COVID-19 lockdown over the Yangtze River Delta Region: An insight into the impact of human activity pattern changes on air pollution variation, Sci. Total Environ. 732 (2020) doi: 10.1016/j.scitotenv.2020.139282

44. K. D. Kanniah, N. A. F. Kamarul Zaman, D. G. Kaskaoutis, and M. T. Latif. COVID19 's impact on the atmospheric environment in the Southeast Asia region, Sci. Total Environ. 736, 139658 (2020) doi: 10.1016/j.scitotenv.2020.139658

45. P. Caligiuri, H. De Cieri, D. Minbaeva, A. Verbeke, and A. Zimmermann. International HRM insights for navigating the COVID-19 pandemic: Implications for future research and practice, Journal of International Business Studies. Palgrave Macmillan Ltd., 1(2020) doi: 10.1057/s41267-020-00335-9

46. B. Wernerfelt. The Resource-Based view of the firm, Strateg. Manag. J. 5, no. April 1983, 171-180 (1984) doi: 10.1002/smj.4250050207

47. J. Barney. Firm Resources and Susteined Competitive Advantage, J. Manage.17, 99120 (1991)

48. I. Ajzen. The theory of planned behavior, Organ. Behav. Hum. Decis. Process. 50, 179-211 (1991) doi: 10.4135/9781446249215.n22. 